\title{
New record of Artibeus aequatorialis Andersen, 1906 (Chiroptera: Phyllostomidae) for northwestern Colombia
}

\author{
Leison Palacios-Mosquera ${ }^{*}$, Yucely del Carmen Copete-Mosquera', Alex Mauricio Jiménez-Ortega', Hugo Mantilla-Meluk², and Paúl M. Velazco³ \\ ${ }^{1}$ Grupo de Investigación Manejo y Gestión de la Vida Silvestre del Chocoana, Facultad de Ciencias Naturales, Programa de \\ Biología, Universidad Tecnológica del Choco, Carrera 22 No.18B - 10, Quibdó, Chocó, 270002, Colombia. Email: lepamo8@gmail. \\ com (LPM), yucacomo@gmail.com (YCCM), alexmauriciojimenez@gmail.com (AMJO). \\ ${ }_{2}^{2}$ Programa de Biología, Universidad del Quindío, Colombia. Email: hugo.mantillameluk@gmail.com (HMM). \\ ${ }^{3}$ Division of Vertebrate Paleontology, American Museum of Natural History 10024, New York. New York, United States of America. \\ Email: pvelazco@amnh.org (PMV). \\ ${ }^{*}$ Corresponding author
}

\begin{abstract}
The Neotropical fruit bats of the genus Artibeus are distributed from southern México to northern Argentina occupying a wide array of different habitats. Of the 14 species present in Colombia, $85.7 \%(n=12)$ occur in the department of Choco. Bat inventories were carried out by the Consejo Comunitario Mayor de Istmina and Medio San Juan (COCOMINSA) and the Universidad Tecnológica del Chocó in the corregimiento de Chiqui Choqui, municipality of Medio San Juan. We present a new record of $A$. aequatorialis for Colombia, that makes an important addition to the bat fauna of Chocoan biogeographic region and is the northernmost record of the species. Our specimen of $A$. aequatorialis was collected in the Chiqui Choqui locality, that belongs to the district of Alto-Atrato San Juan that is a poorly study area, whose diversity is threatened by human activities, like deforestation and mining activities.

Los murciélagos frugívoros Neotropicales del género Artibeus extienden su distribución desde el sur de México hasta el norte de Argentina ocupando una gran variedad de habitas. De las 14 especies registradas para Colombia el $85.7 \%(n=12)$ ocurren en el departamento del Chocó. Muestreos con redes de nieblas fueron llevados a cabo durante un inventario de murciélagos realizado cabo por el Consejo Comunitario Mayor de Istmina y Medio San Juan (COCOMINSA) y la Universidad Tecnológica del Chocó en el corregimiento de Chiqui Choqui, municipio de Medio San Juan. Se presenta un nuevo registro de Artibeus aequatorialis para Colombia, el cual constituye una adición significativa en la distribución de este taxón en la región del Chocó Biogeográfico-colombiano y el registro más norte conocido para esta especie en su distribución. El espécimen de A. aequatorialis fue colectado en la localidad de Chiqui Choqui, la cual forma parte del distrito Alto-Atrato San Juan que corresponde una zona pobremente muestreada en su fauna y flora, cuya diversidad se encuentra amenazada por presiones antrópicas como la tala selectiva y la minería a cielo abierto.
\end{abstract}

Key words: bat; distribution; diversity; pacific coast; Stenodermatinae.

C 2019 Asociación Mexicana de Mastozoología, www.mastozoologiamexicana.org

\section{Introduction}

The Neotropical fruit bats of the genus Artibeus Leach, 1821 are distributed from southern México to northern Argentina and currently includes 23 species grouped into two subgenera: Artibeus and Dermanura (Hoofer et al. 2008; Marques-Aguiar 2008; Redondo et al. 2008; Solari et al. 2009; Cirranello et al. 2016). For decades, there has been controversy regarding whether all the "Artibeus" species should be grouped into three genera (Artibeus, Dermanura, and Koopmania), two genera (Artibeus and Dermanura) or only one genus (Artibeus). Recently Baker et al. (2016) and Cirranello et al. (2016) settle this controversy by supporting with molecular and morphological data the recognition of a single genus with two subgenera (Artibeus and Dermanura).

Out of the 23 species, 14 occur in Colombia, seven of the subgenus Artibeus: A. aequatorialis Andersen, 1906; A. amplus Handley, 1987; A. concolor Peters, 1865; A. jamaicensis Leach, 1821; A. lituratus (Olfers, 1818); A. obscurus (Schinz, 1821); A. planirostris (Spix, 1823), and seven of the subgenus Dermanura: A. anderseni Osgood, 1916; A. bogotensis (Andersen, 1906); A. glaucus Thomas, 1893; A. gnomus Handley, 1897; A. phaeotis (Miller, 1902); A. ravus (Miller,
1902); and A. rosenbergi Thomas, 1987 (Ramírez-Chaves et al. 2016).

Artibeus aequatorialis is know from west of the Andes Mountains from northern Perú, northward throughout western Ecuador to Colombia (Larsen et al. 2010). The northernmost vouchered record of the species occurs in the department of Valle del Cauca [Rio Raposo $3^{\circ} 43^{\prime} \mathrm{N} ;-77^{\circ}$ 08' W] (Larsen et al. 2010). Even though A. aequatorialis is considered by some authors to occur in the departments of Chocó and Nariño (e. g., Solari et al. 2013), there are no vouchered record that support this assertion. Herein, we report the northernmost vouchered record of this species, extending its distribution into the department of Chocó (Figure 1).

\section{Methods}

During a bat inventory carried out by the Consejo Comunitario Mayor de Istmina and Medio San Juan (COCOMINSA) and the Universidad Tecnológica del Chocó along the left bank of the San Juan river ( $5^{\circ} 2^{\prime} 16.26^{\prime \prime} N,-76^{\circ} 43^{\prime} 23.4^{\prime \prime} \mathrm{W}, 45$ $\mathrm{m})$, corregimiento de Chiqui Choqui, municipality of Medio San Juan (Figure 1), one adult male specimen of $A$. aequatorialis was collected with a mist-net at a height of $1.60 \mathrm{~m}$ 
from the ground in a secondary growth habitat that is in the process of recovery after being the subject of intensive gold and platinum mining activities. The specimen was deposited in the Colección Masozoológica del Chocó, Universidad Tecnológica del Choco $(\mathrm{CMCH})$, in Quibdó, Chocó, Colombia. The following species were also captured in this locality: Artibeus lituratus, A. ravus, Carollia castanea, C. perspicillata, and Uroderma convexum.

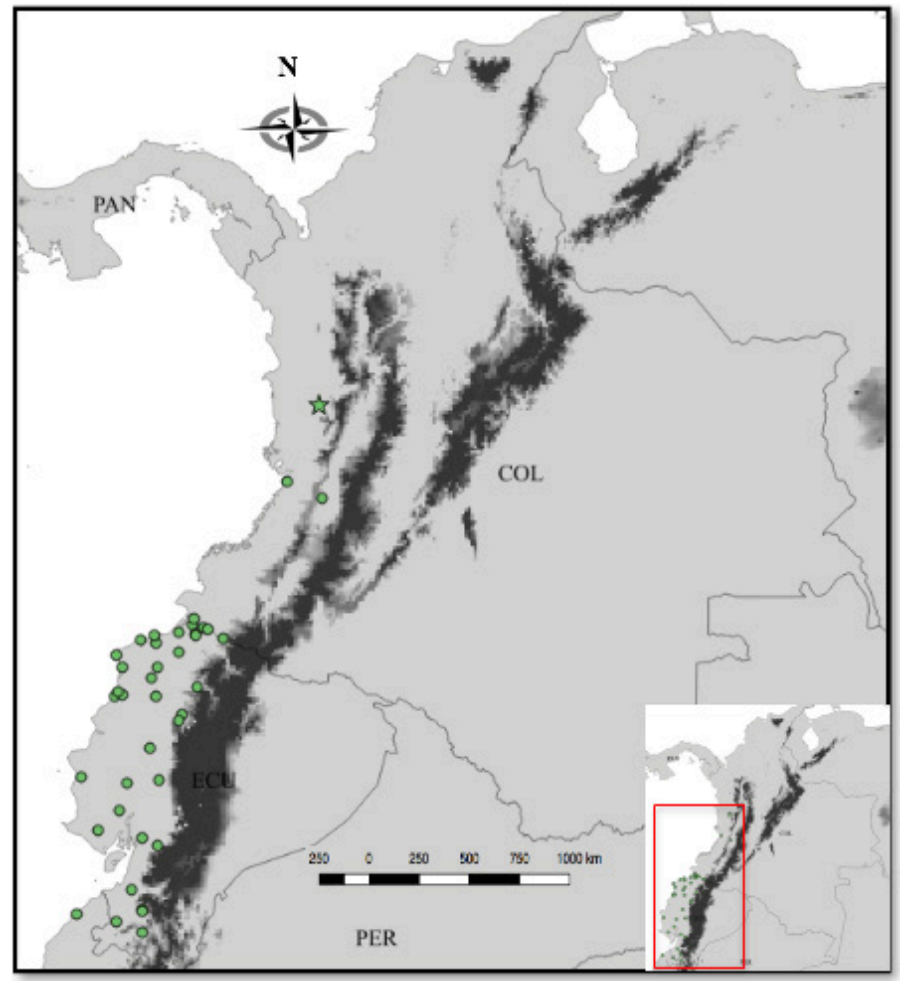

Figure 1. Geographic distribution of Artibeus aequatorialis and the new record (star) in the department of Chocó, western Colombia.

\section{Results}

Our specimen $(\mathrm{CMCH} 1410)$ was captured on 12 October 2011 at 21:48 $\mathrm{h}$ and is preserved as a study skin and skull. It was identified based on the characteristics described in Larsen et al. (2010). Standard external measurements (in mm) and weight (in gr) are as follows: total length, 78.3; length of hind foot, 17.1; length of forearm, 64.3; length of ear, 24.0; weight, 45.9. Selected craniodental (in $\mathrm{mm}$ ) measurements based on Larsen et al. (2010) were taken with a digital caliper (0.01 $\mathrm{mm}$ precision) and are provided in Table 1 .

Our specimen externally presents the following diagnostic characteristics of Artibeus aequatorialis: brown dorsal fur with pale white bands at the base, pale brown ventral fur with whitish tips, almost imperceptible facial lines, white wing tips, broad inter-femoral membrane with V-shaped notch of almost naked appearance, with few short hairs in ventral and dorsal view.

Our specimen has a large skull (GSL $=30.28$ ), a fairly robust dentition. The sagittal crest, as well as the pre- and postorbital processes are slightly developed; the face is relatively short with a slightly arched appearance; and the P4 presents two cusps in the proximal face (Figure 2). Both the protocone and the hypocone of the upper first molar (M1)
Table 1. Craniodental measurements of the new record of Artibeus aequatorialis from the department of Chocó, Colombia ( $\mathrm{CMCH} 1410)$. Mean and range of specimens recorded by Larsen et al. (2010).

\begin{tabular}{lccc}
\hline & CMCH 1410 & \multicolumn{2}{c}{ Larsen et al. $(2010)$} \\
\hline Male & Males $(n=37)$ & Females $(n=42)$ \\
\hline CIL & 30.28 & $29.43(27.88-30.63)$ & $29.61(28.54-30.84)$ \\
SH & 26.91 & $26.37(24.82-27.50)$ & $26.54(25.51-27.75)$ \\
MB & 12.02 & $13.12(12.27-13.91)$ & $13.00(12.29-13.96)$ \\
BRW & 14.41 & $15.55(14.32-16.60)$ & $15.50(14.35-16.25)$ \\
ZB & 13.38 & $13.96(12.78-14.60)$ & $13.93(13.28-14.61)$ \\
POW & 17.96 & $17.87(16.66-18.93)$ & $17.97(16.63-18.99)$ \\
C1C1 & 7.80 & $7.35(6.94-7.77)$ & $7.40(6.85-8.01)$ \\
M2M2 & 8.96 & $8.64(7.85-9.20)$ & $8.52(7.92-9.05)$ \\
PL & 13.21 & $13.40(12.62-14.16)$ & $13.35(12.83-14.22)$ \\
MXTR & 14.53 & $14.24(13.15-14.89)$ & $14.35(13.65-15.19)$ \\
MIL & 10.91 & $10.64(9.88-11.39)$ & $10.48(9.77-11.08)$ \\
MLT & 19.78 & $19.38(18.31-20.55)$ & $19.45(18.54-20.36)$ \\
C1C1 & 11.99 & $11.74(10.86-12.56)$ & $11.62(10.47-12.36)$ \\
\hline & 4.91 & $4.79(4.37-5.14)$ & $4.73(4.39-5.30)$ \\
\hline
\end{tabular}

are moderately developed, with a broad heel. The upper second molar (M2) is clearly smaller; with its expanded paracone and a well-developed labial cingulum. The M1 and $\mathrm{M} 2$ are separated by a diastema (Figure $2 \mathrm{~B}$ ). The third lower molar (m3) is small (Figure $2 \mathrm{C}$ ). The craniodental measurements obtained for our specimen fall within the range of variation for the species (Table 1; Larsen et al. 2010).

The habitat at the site of capture is a river bank forest with clay soils and open understory characterized by the

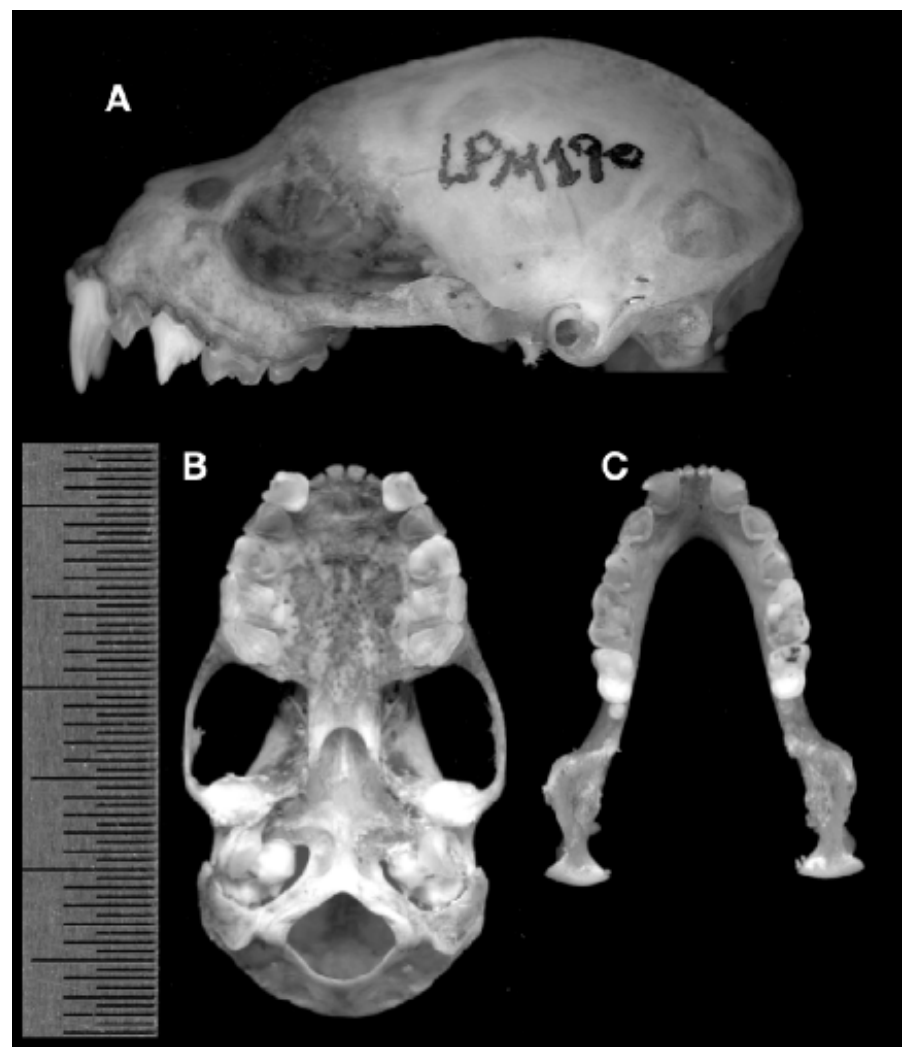

Figure 2. Dorsal, ventral, and lateral views of the skull and also dorsal and lateral views of the mandible of Artibeus aequatorialis (CMCH 1410). See Table 1 for measurements. Scale bar $=0.05 \mathrm{~mm}$. 
presence of Cyperus luzulae (L.) Retz., Scleria secans (L.) Urb., Croton killipianus Croizat, Isertia pittieri (Standl.), Cecropia hispidissima Cuatrec, Cecropia peltata L., Mimosa pudica L., Vismia baccifera L. Planch. \& Triana, Acacia mangium, and Cespedesia spathulata (Ruiz \& Pavon). This site, now under recovery, was subject to intensive gold and platinum mining activities.

\section{Discussion}

Before the revision of Larsen et al. (2010) Artibeus aequatorialis was considered one of the five subspecies of $A$. jamaicensis, and because of that its conservation status of is unknown. Neither, IUCN or national red lists include $A$. aequatorialis in their accounts, but there is an urgent need to determine its conservation status since this species has a restricted distribution and many of the populations occur in areas that face many threats, including deforestation, mining activities, etc.

In the last decade, the number of new bat records reported for the Chocó biogeographic region in Colombia has increased exponentially: Diclidurus ingens, Lonchophylla chocoana, Lonchophylla orcesi, Artibeus rosenbergi, Micronycteris giovanniae, Platyrrhinus matapalensis, P. nitelinea, among others (Davalos 2004; Albuja V et al. 2005; Velazco 2005; Fonseca et al. 2007; Hoofer et al. 2008; Mantilla-Meluk et al. 2009; Velazco and Gardner 2009). The specimen reported here represents the first record of $A$. aequatorialis in the department of Chocó and extend the known northern limit of the species distribution by more than $153 \mathrm{~km}$ (Figure 1).

\section{Acknowledgements}

We are grateful to the Consejo Comunitario Mayor de Istmina COOMINSA, the comunidad de Chiqui Choqui for their support during the fieldwork; to Eida Annier for allowing us to work in this expedition.

\section{Literature cited}

Albuja V, L., A. L. Gardner, and G. Graves. 2005. A new species of Lonchophylla Thomas (Chiroptera: Phyllostomidae) from Ecuador. Proceedings of the Biological Society of Washington 118:442-449.

Baker, R. J., S. Solari, A. L. Cirranello, and N. B. Simmons. 2016. Higher level classification of phyllostomid bats with a summary of DNA synapomorphies. Acta Chiropterologica 18:1-38.

Cirranello, A. L., N. B. Simmons, S. Solari, and R. J. Baker. 2016. Morphological diagnoses of higher-level phyllostomid taxa (Chiroptera: Phyllostomidae). Acta Chiropterologica 18:39-71.

DÁvalos, L. M. 2004. A new chocoan species of Lonchophylla (Chiroptera: Phyllostomidae). American Museum Novitates 3426:1-14.

Fonseca, R., S. R. Hoofer, C. Porter, C. A. Cline, D. E. Parish, F. G. Hoffmann, and R. J. Baker. 2007. Morphological and molecular variation within little Big-eared bats of the genus Micronycteris (Phyllostomidae: Micronycterinae) from San Lorenzo, Ecuador. Pp. 721-746 in The Quintessential Naturalist: Honoring the Life and Legacy of Oliver P. Pearson
(Kelt, D. A., E. P. Lessa, J. Salazar-Bravo, and J. L. Patton, eds.). University of California, Publications in Zoology 134. University of California Press. Berkeley, U. S. A.

Hoofer, S. R., S. Solari, P. A. Larsen, R. D. Bradley, and R. J. Baker. 2008. Phylogenetics of the fruit-eating bats (Phyllostomidae:Artibeina) inferred from mitochondrial dna sequences. Occasional Papers of the Museum, Texas Tech University 277:1-16.

Larsen, P. A., M. R. Marchan-Rivadeneira, And R. J. Baker. 2010. Taxonomic status of Andersen's fruit-eating bat (Artibeus jamaicensis aequatorialis) and revised classification of Artibeus (Chiroptera: Phyllostomidae). Zootaxa 2648:46-60. Mantilla-Meluk, H., A. M. Jimenez-Ortega, L. Palacios, and R. J. BAKER. 2009. Unexpected finding of Diclidurus ingens, Hernández-Camacho, 1955 (Chiroptera, Emballonuridae), in the Colombian Biogeographic Chocó. Mastozoología Neotropical 16:229-252.

Marques-Aguiar, S. A. 2008. Genus Artibeus Leach, 1821. Pp 301-321 in Mammals of South America, Volume 1: Marsupials, Xenarthrans, Sherws, and Bats (Gardner, A. L., ed.), . The University of Chicago Press. Chicago, U. S. A.

Ramírez-Chaves, H. E., A. F. SuÁrez-Castro, and J. F. González-Maya. 2016. Cambios recientes a la lista de los mamíferos de Colombia. Mammalogy Notes, 3: 1-9.

Redondo, R. A. F., L. P. S. Brina, R. F. Silva, A. D. Ditchifeld, and F. R. SAntos. 2008. Molecular systematics of the genus Artibeus (Chiroptera: Phyllostomidae). Molecular Phylogenetics and Evolution 49:44-58.

Solari, S., S. R. Hoofer, P. A. Larsen, A.D. Brown, R. J. Bull, J. A. Guerrero, J. Ortega, J. P. Carrera, R. D. Bradley, and R.J. Baker. 2009. Operational criteria for genetically defined species: analysis of the diversification of the small fruit-eating bats, Dermanura (Phyllosomidae: Stenodermatinae). Acta Chiropterologica 11:279-288.

Solari, S., Y. Muñoz-Saba, J. V. Rodríguez-Mahecha, T. R. Defler, H. E. Ramírez-Chaves, and F. Trujillo. 2013. Diversidad, endemismo y conservación de los mamíferos de Colombia. Mastozoologia Neotropical 20:301-365.

VelazCo, P. M. 2005. Morphological phylogeny of the bat genus Platyrrhinus Saussure, 1860 (Chiroptera: Phyllostomidae) with the description of four new species. Fieldiana Zoology, New Series, 105:1-53.

Velazco, P. M., and A. L. Gardner. 2009. A new species of Platyrrhinus (Chiroptera: Phyllostomidae) from western Colombia and Ecuador, with emended diagnoses of $P$. aquilus, $P$. dorsalis, and P. umbratus. Proceedings of the Biological Society of Washington 122:249-281.

Associated editor: Rafael Avila Submitted: April 18, 2018; Reviewed: May 30, 2018; Accepted:September 20, 2018; Published on line: October 15, 2018. 
48 THERYA Vol. 10 (1): 45-47 